\title{
Communication Strategies in Providing Good Government Education Through Social Media: A Case Study at the Parliament of the Republic of Indonesia
}

\author{
${ }^{1}$ Anindya Larasati, ${ }^{2}$ Achmad Jamil*, ${ }^{3}$ Rizki Briandana \\ ${ }^{123}$ Universitas Mercu Buana, Jakarta, Indonesia
}

\begin{abstract}
Objective: To analyze the communication strategy of the parliament of the Republic of Indonesia in providing good government education through social media. Methods: Case studies are used as a method in this research, and data collection techniques using in-depth interviews. The basis for selecting informants used a purposive technique by looking at the criteria for informants. Results: The results showed that the communication strategy implemented by the DPR-RI has shown success in educating the public regarding good govenment. The strategy of the parliament's news bureau to absorb the information needed by the public regarding the performance of the parliament is an important key to success. Conclusion: The good governance through Instagram social media was very effective in publishing the performance of leaders and members of the parliament.
\end{abstract}

Keywords:

strategy communication, good governance, education, Republic of Indonesia

Article Received: 18 October 2020, Revised: 3 November 2020, Accepted: 24 December 2020

\section{INTRODUCTION}

The People's Representative Council of the Republic of Indonesia (DPR-RI) is one of the highest state institutions (Muda et al., 2018). The DPR-RI has a legislative function, a budget function, and a supervisory function. To carry out its functions, the DPR-RI has the duties and authorities, among other things: forming laws, stipulating the State Budget, supervising and accommodating and following up on the aspirations of public complaints (Presidential Decree No.13, 1994).

In government organizations, the DPR-RI Parliamentary News Bureau also has an important role in achieving organizational goals (Nasution, 2017). However, the role played by the DPR-RI Parliamentary News is slightly different from the existing government, which focuses on business and produces products. Here, the news of the DPR-RI will intersect with an intangible problem, namely public sympathy for news that cannot be obtained anywhere other than the news from the DPR RI Parliament (Ahmad \& Ahmad, 2019; Labolo et al., 2020).
According to Bambang Soesatyo, the Head of DPR-RI, reminded the importance of accountability and transparency in the performance of each parliamentary member in carrying out his duties and functions as people's representatives (www.wartakota.tribunnews.com on April 15, 2019). Publication is important so that people know what their representatives are doing in the parliament (Prihatini, 2019). The Chairperson of the DPR-RI requested that members of the council publish their activities through their personal social media; this was done so that the public could be aware of activities at the DPR, during work visits or in the constituency. The General Secretary together with the parliamentary news bureau gave added value to social media so that it could produce positive perceptions for the people of Indonesia, especially in the millennial generation (Ahmad \& Ahmad, 2018)

In this context the DPR-RI utilizes information and communication technology through social media as the main media in delivering information to the public. The use of social media is related to the high use of the Internet and social media in Indonesia. Results of 
the Survey of the Indonesian Internet Service Providers Association (APJII) found that the number of Internet users in Indonesia in 2019 reached 171.18 million people or grew by 27.91 million compared to the previous one. With a penetration of 64.8 percent of the total population of 264.16 million people, this shows that the population of Indonesia literate with the Internet.

On the website (www.dpr.go.id on November 5 2019), the Secretary-General stated that the DPR-RI is currently proceeding towards the Modern Parliament. "We have declared Open Parliament to proceed in a multilateral mechanism through the Open Government Partnership (OGP) to encourage the values of openness, transparency, democracy towards the formation of Good Governance. The DPR-RI Instagram account has 304,000 followers. This Instagram has uploaded 3,055 photos and videos of the activities of leaders and members of the DPR-RI.

The existence of public information disclosure is one form of the implementation of good governance (Jameel et al., 2019; Panjaitan et al., 2019). In general, there are several characteristics and values inherent in good governance practices (Hertati et al., 2019). It is hoped that the DPR-RI Instagram account will create a positive education for the community. However, the positive education that results from the photos and videos uploaded on the DPR-RI Instagram sometimes disappoints its followers, because in fact there are still many members of the council who are caught in cases, such as one of which is a corruption case that causes these images to drop and in these accounts everything. In this context, social media plays an important role in educating the public regarding information disclosure by the DPR-RI. The activities of DPRRI members and leaders are illustrated in terms of performance, which is expected from the uploading of photos and videos to improve the image of the DPR-RI for the better. A good image really depends on the efforts of a person or group to publish it. Based on the background, the main objective of this study is to analyze the communication strategy carried out by the parliament in realizing education good governance through the media of Instagram.

\section{CONCEPTUAL FRAMEWORK OF THE STUDY}

\section{Social Media as Communication Platform in Digital Era}

According to Gane \& Beer (2008) in the current global world, the world community has entered an era of knowledge-based society and an era of information and communication that began and was marked by the development of Technology, Communication and Information (ICT), including information in the mass media which also tends to turn to new media.

The development of communication technology and the internet also brought considerable influence in Indonesia (Mulyana et al., 2020). Among the most widely used is social networking sites or social media, which is now a trend in the lives of the world community, not least in Indonesia. According to Dwityas et al., (2020) "Social media is often used to describe the collection of software that enables individuals and communities to gather, communicate, share, and in some cases collaborate or play" which means social media is often used to describes a collection of software that allows individuals and communities to gather, communicate, share, and in some cases collaborate or play.

Social media sites like Facebook, Twitter, Instagram, etc., are web-based services that allow users to create profiles, view available user lists, invite or accept friends to join the site, share posts, images or videos that can be seen by his network, and vice versa, see the writings, images, and videos uploaded or shared by his network, including organizations, in the social media (Nadeem et al., 2020; Dwityas \& Briandana, 2017; Ahmad \& Sahar; 2019). 
According to Cuponation research results quoted from article tirto.id (2019) Indonesia is the fourth highest Facebook and Instagram user in the world, which is one of the most popular social media today. Using social media in daily activities is common, starting from the younger generation and those who are already in the senior category, this is also evident from the infographics released by the research company We Are Social, that active users of social media in Indonesia in the period January 2018 - January 2019 has reached 150 million of the total population in Indonesia as many as 268.2 million people, which means about $56 \%$ of the population. This study is part of a new media study that looks at the role of internet use, especially Instagram in government agencies.

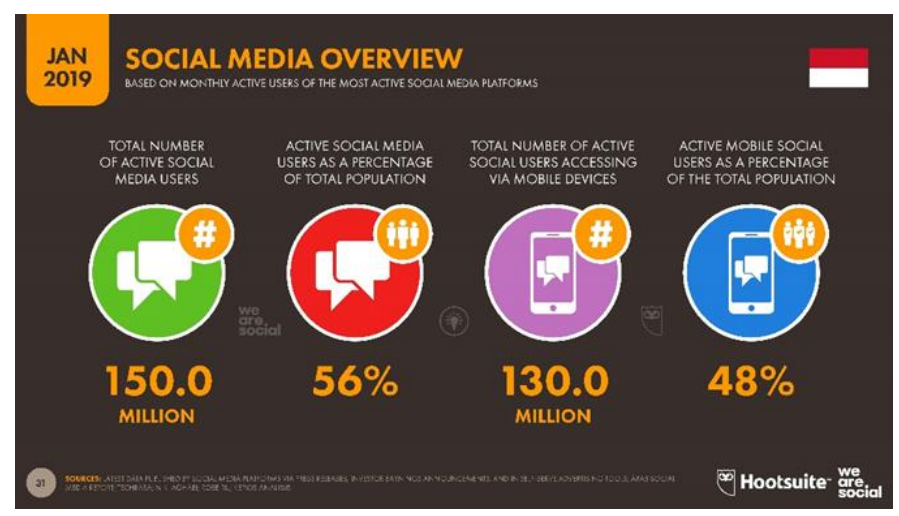

Figure 1. Social Media Overview in Indonesia

Source: wearesocial.com

Social media is a media platform that focuses on the existence of users that facilitate them in their activities and collaboration (Gerlich et al., 2010). Therefore, social media can be seen as facilitator medium that strengthens the relationship between users as well as social ties (Barker \& Mathijs, 2012). Online facilitators strengthen the relationship between users as well as a social bond (Obicci, 2019; Razzaq, Maqbool, \& Hameed, 2019; Rex, 2019)

Instagram is a platform of social media that can deliver messages for communicating with a broad audience by sharing photos or videos, which include other features such as DM (direct message), comment, and love or like (Anderson \& Jiang, 2018; Jamil et al., 2019). Instagram comes from insta-telegram; giving likes and commenting on photos that have been uploaded by other users can establish communication between fellow Instagram users themselves (Safko \& Brake, 2009). Follower is also one important element, and the numbers of pins of the followers like greatly affect whether the image can be a picture that is popular or not (Sutono et al., 2018). Finding friends on Instagram can be done through their friends who also use Instagram or share photos uploaded via social networks like Twitter and Facebook.

\section{Communication Strategy}

According to Datig (2018) communication strategy has three areas of content strategy tools, Working definition and Questions to consider. This research uses the content strategy tools as follows: (picture)

Table 1. Content Strategy Tools

\begin{tabular}{|c|c|c|}
\hline $\begin{array}{l}\text { Content } \\
\text { Stategy Tool }\end{array}$ & Working definition & Questions to consider \\
\hline $\begin{array}{l}\text { Content } \\
\text { audit }\end{array}$ & $\begin{array}{l}\text { The process of creating } \\
\text { detailed spreadsheets of } \\
\text { all online library } \\
\text { content, including } \\
\text { indentifying } \\
\text { information }\end{array}$ & $\begin{array}{l}\text { - What content does the library already } \\
\text { have available to users? } \\
\text { - What is the quality of the content? } \\
\text { - Is the content clear, accurate, and up-to- } \\
\text { date? }\end{array}$ \\
\hline User persona & $\begin{array}{l}\text { A graphic and textual } \\
\text { respresentation of a } \\
\text { patron type }\end{array}$ & $\begin{array}{l}\text { - Who are the library patrons? } \\
\text { - What does the library help them do? }\end{array}$ \\
\hline
\end{tabular}




\begin{tabular}{|c|c|c|}
\hline & & $\begin{array}{l}\text { - Is library content reaching them where } \\
\text { they are? }\end{array}$ \\
\hline $\begin{array}{l}\text { Content } \\
\text { vision } \\
\text { statement }\end{array}$ & $\begin{array}{l}\text { A statement of purpose } \\
\text { that provides guidance } \\
\text { for all content }\end{array}$ & $\begin{array}{l}\text { - Why does the library create and publish } \\
\text { content? } \\
\text { - How can content help the library work } \\
\text { loward achieving institutional goals? }\end{array}$ \\
\hline $\begin{array}{l}\text { Channel } \\
\text { strategy }\end{array}$ & $\begin{array}{l}\text { The process of } \\
\text { strategizing content } \\
\text { across multiple } \\
\text { channels and } \\
\text { acknowledging that } \\
\text { channels have different } \\
\text { norms }\end{array}$ & $\begin{array}{l}\text { What channels (e.g. Facebook, } \\
\text { Instagram, Twitter) do library patrons } \\
\text { use? } \\
\text { What norms govern different social } \\
\text { media channels? } \\
\text { How can new library content be } \\
\text { repurposed across multiple channels? }\end{array}$ \\
\hline
\end{tabular}

Source: (Datig, 2018)

\section{Good Governance}

The World Bank defines governance as "the way state power is used in managing economic and social resources for the development of society" (Jameel et al., 2019). According to the United Nations Development Program (UNDP) defines governance as "the exercise of political, economic, and administrative authority to manage a nation's affair at all levels". Beeri et al., (2019) establishes the characteristics of good governance, which includes: Participation, Rule of Law, Transparency, Responsiveness, Consensus Orientation, Equity, Effectiveness and Efficiency, Accountability.

The World Bank places more emphasis on the way the government manages social and economic resources for the benefit of community development, while UNDP places more emphasis on political, economic, and administrative aspects in managing the country. Political governance refers to the policy/ strategy formulation process (Panjaitan et al., 2019). Economic governance refers to the decision-making process in the economic field, which has implications for the problem of equity, poverty reduction, and improvement of quality of life (Panjaitan et al., 2019). Administrative governance refers to the system of policy implementation.

\section{Theoretical Framework}

In this context, researchers contextualize the theoretical framework by linking the concepts and theories used in this study.

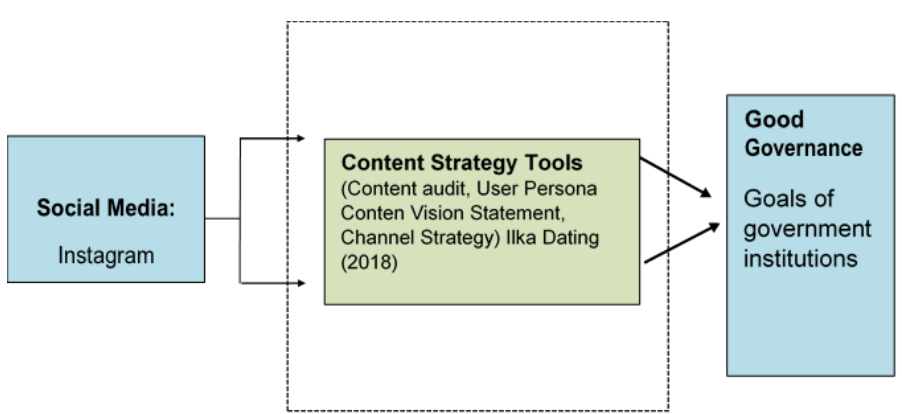

Figure 2. Theoretical Framework

Source: researcher (2020)

Figure 2 explains that a message in social media to be published, especially on Instagram, must have a creative strategy so that, when the strategic decision makers of the organization make a decision, they must interact with the public through their function, which makes their decisions have an impact on the public interest or because of the organization. In this case, a relationship that helps with the public is needed in implementing policies and achieving organizational goals.

In addition, parliamentary reporting has value in strategic management because it allows organizations to enact parts of the environment that represent other parts of management that are 
unlikely to identify and help strategic decision makers determine which stakeholders are most important. By acting as a content strategist and creative strategy maker in making news, it enters into strategic management in organizations which use 5C in making news, namely, collaborating, communicating, complecting, connecting and combining. Parliamentary reporting has more power in including aspects of public understanding and two-way communication in all organizational activities, including in managing public information disclosure in the DPR-RI, where the management of public information is formed on the basis of demands for good governance which requires the existence of accountability, transparency and public participation in every process of public policy.

\section{RESEARCH METHOD}

This research is included in qualitative research, which interacts with the facts studied. This research used a case study method to find out how the DPR-RI Instagram communication strategy in realizing good governance through public information, is included in the form of expansive case studies (Yin, 2006). The focus of this study is on the DPR-RI Instagram creative content strategy, cases are chosen to gain a deeper understanding and do not represent certain phenomena, this case was chosen because it is interesting, intrinsic case study (Yin, 2013). This research was conducted at the DPR-RI Secretary General in charge of the media for one year; June 2019 to April 2020.

The primary data collection technique in this study is the in-depth interview method, and researchers used a purposive informant selection technique. Purposive is carried out in order to select certain informants who are considered competent in explaining how the message creativity strategy carried out by the Secretary General of the DPR-RI in an effort to realize good governance.
Determination of sources in this study is based on the research method, namely taking sources with the consideration of sources that know and are relevant to the problem the writer wants to know (Sugiyono, 2012). Some of the criteria for these sources include:

1. Resource persons have long and intensively integrated into information activities. Besides that, he also lives seriously as a result of his long involvement with the environment or the activity concerned. This is usually characterized in providing information about something being asked.

2. Resource persons are still actively or fully involved in the environment or activities that concern the author.

Based on the above criteria, the resource persons who became informants in the study were Fajar Surya and Dipa Natalio, content creators in implementing the message creativity content strategy through social media Instagram.

\section{FINDINGS AND DISCUSSION}

The development of media is currently so massive, both mass media and social media. Currently, social media is inseparable from everyday human activities, almost all Indonesian millennial generations currently have social media accounts, including Facebook, Instagram, Twitter and YouTube. Ownership of social media cannot be separated from the demands of a flexible era. Not only the millennial generation, government and private institutions to compare their work and production to the general public have also carried out the use of social media.

For this reason, researchers conducted research related to content strategies to improve good governance by using Instagram social media. This study is to determine the extent of the influence of social media in comparing the performance of DPR-RI members by conducting in-depth interviews with the DPR-RI social media management team. 


\section{Content Strategy Tools on Social Media}

Technological advances in the era of globalization will bring big changes, especially the emergence of social networks, such as Instagram, Facebook and Twitter. Social media is used as a communication strategy to make a good government through public information. This is what the DPR-RI has done by utilizing social media such as Instagram that can be accessed by its followers. In this process, it requires attractive message packaging in creating content before posting on social media.

The main purpose of a content strategy is to use words and data to create content that is clear and supports interactive and meaningful experiences. In line with this, Ilka Datig stated that a content strategy can be used with a concept that needs to use a strategy to make the content interesting, while some of the strategies it uses are the following steps: (1) content audit; (2) user persona; (3) content vision statement; (4) channel strategy.

\section{Content Audit}

Content audit is used for the first step as a research to find out information needs that are evolving and needed by the public. Before manager shares the content, they are analyzing what issues become public discussions. As explained by DPR-RI Instagram Content Creator, Fajar Surya, as the Graphic Designer who produces interesting content, and make the content meet the needs of the community, the social media manager first observes the Government Social Media account and netizens, so that the information it is given not what the DPR-RI wants but which is the discourse and needed by the community.

"So I made it easy to understand and until now the news to the public is with the existence of script writing, so my team and I were asked to make it interesting, the strategy we are doing is where we observe it, usually to government agencies. So when we got it, we made a story board and story line" (Personal Communication, informant 1).

This means that the DPR-RI social media management team first made observations regarding what issues or news the public was waiting for regarding the DPR-RI news. After conducting observations and research, knowing what information is being awaited, it is the discussion that will eventually become content similar to what was conveyed by the creative director of social media of DPR-RI Dipa Natalio.

"Every day there are many of our agendas, there can be a meeting in a day. Every agenda should always be covered. If there are hot content like Hajj funds or BPJs, it is usually what our netizens are waiting for. Well, usually we post even though it is very late at night" (Personal Communication, informant 2).

Apart from managing the issues themselves based on the results of analysis and research, the social media team also took content from Parliament TV, but it was re-edited by the social media team to follow the style of content on Instagram.

\begin{abstract}
"We also took it from Parliament TV, but we channeled the sources to the DPR RI social media. If asked whether this is correct or not, because this is new media that we are launching. DPR to change people's mindset. Because social media was formed to make this institution even better ". (Personal Communication, informant 2)
\end{abstract}

Making the DPR-RI look good and in accordance with the needs of the community is the goal of the social media team. In addition, another purpose of using social media is to make the DPR a good and open government in providing services and responding to community needs. It is undeniable 
that the presence of social media today has greatly changed the circulation of information, where people usually get information or news from television screens, newspapers and website channels or online media which takes a little slow. While social media disseminates information quickly in the form of photos and videos, of course institutions like the DPR-RI should use social media to spread all their activities.

\section{User Persona}

In the process of editing content to be published based on the recommendations of the analysis team and editor. However, not all of the results of the analysis team's recommendations were published because the factor of late or the issue was over or the public was discussing a hot issue. That is, each post that will be published does not fully follow the analysis team's recommendation to meet the target content per day that has been determined by the leader, but the post that will be published must follow the development of issues that are the main issues in the community. According to Surya, examples of content often eagerly awaited by the public in this case followers of DPR-RI Instagram is actual problems, such as BPJS contribution fees and Hajj fund management. This issue is interesting for the public because it involves funds collected from the community and managed by the government. Instagram managers are required to always keep updated of issues evolution in the community, in anticipation of the rapid dynamics of the issue.

"Now, social media has made its own way, how do we make a content strategy that is correlated like yesterday's plastic waste. The message that was delivered was that DPR reduces plastic waste. During the meeting, the DPR used glasses and glass bottles. Well, usually because of that the public is waiting, I can see from their comments that they are missing what else will be done with the DPR's social media. So it's already starting to show that the
DPR has advanced one initial stage towards good governance" (Pesonal Communication, informant 1).

In addition, the DPR-RI Instagram Medsos team is also required to consistently maintain content for the publication, because Instagram users who follow the DPR-RI Instagram account do not know the time, thus requiring the team to continue working to present the required information.

"Maintaining the content constancy, for example the content that we have created now does not change the graphics. For example, these meetings are what we process. How do we summarize the sentence so that the term if on social media is click bait, click verse is a bait sentence at the beginning so that a public is curious about our content. Usually when there is a highlight on social media, now the strategy is how do we make highligh incentives so that people want to continue and curious about the content that we are going to publish" (Pesonal Communication, informant 1).

\section{Content Vision Statement}

According to Dipa Natalio, Creative Director media, this content tries to present actual information to the public. The aim is expected to improve the image of the DPR-RI better in accordance with the vision and mission of the DPR-RI. The information submitted is based on community needs. Furthermore, according to Dipa Natalio, the DPR-RI social media made Instagram as a place to deliver the aspirations of the people. In the comments section, the public can deliver their problems or hopes. The comments section can contain input, appreciation or even verbal abuse for the leadership or members of the board.

"In order to make the DPR image warmer to the public, go back to the previous one 
so that good governance is formed and created by this. And further open the public's insight that the performance of the dpr and us is a barometer of the needs of the people who are out there. So if society wants what, we are the barometer, the real barometer is from us. The DPR's performance is actually up to us" (Pesonal Communication, informant 1).

Serving the community is the main task of DPRRI Members after being elected by the community to represent their aspirations to the Central Government. For this reason, the management of Instagram social media is devoted to publishing all activities of the DPR-RI for the wishes of the people. Intagram social media is the most appropriate and fast media in distributing information to the public, so that the management of the DPR-RI Instagram social media content must be based on the main vision and mission of the DPR-RI. On that basis, it can be said that the DPR-RI social media team has become a barometer of the DPR-RI's information dissemination to the public. This is inseparable from the strength of social media, especially Instagram, which is the application of the most users.

"So indeed the accessibility and delivery to the public can be faster. So the key is social media so that the delivery to the community is fast and to anyone who is quick to accept it. Especially the millennial because millennial children are currently very sensitive to national politics, we have to respond to their enthusiasm on Instagram with content that shows the performance of DPR-RI Members" (Pesonal Communication, informant 2).

\section{Channel Strategy}

Dipa Natalio said that the selection of Instagram as a place to publicize the performance of DPR-RI Members is very appropriate, because social media is very open and easily accessible to people everywhere. Social media is used so that people can communicate interactively with the DPR-RI. The measurement of the success of the DPR-RI Instagram management can be seen from the response of the people who followed the DPRRI Instagram.

"There are 439,000 followers on Instagram and that's a lot from other social media. In posting content to Instagram it varies such as videos, photos and graphic info. Three to four videos a day, photos and graphic info are uncertain" (Pesonal Communication, informant 2).

The use of Instagram as a media for publication of the work of DPR-RI members has undergone a better change as the main objective. There have been many positive responses to the management method that has fulfilled the public's wishes. Not only that, all the activities of DPR-RI members is also known, from the plenary session to work visits to regions and abroad. This means that so far the DPR-RI's social media management is not very effective, and currently it is getting better with the presence of a good management team and understanding strategies in managing social media. The measure of the success of the DPR-RI's Instagram social media management is from the response of the people who follow the DPR-RI Instagram. Although there are those who are not aware of the work of the leadership and members of the DPR-RI, the community also conveys many positive responses and they know the work of the DPR-RI from offices to visits to villages.

The communication channels used by the DPR RI Social Media mostly use non-personal communication, such as social media, YouTube, Facebook, Twitter and Instagram. However, in this study the researchers only took Instagram as the object of research where the object was used as a medium to compare the performance of DPRRI members to the public. A media channel 
selection strategy is critical to ensuring the right time and place for posting, and considering what types of content are most effective at reaching users and creating engagement. In this context, Instagram was designed as a place for interesting photography.

\section{Discussion}

The emergence of various social media cannot be separated from the development of technology and the internet (Rauniar et al., 2014). The combination of written text, audio-visual content, and photography in the digital realm is due to the convergence of media (Briandana, Pribadi, et al., 2020; Mulyana et al., 2019). In this millennial era, society is developing rapidly in various fields that are supported by the level of digital media access that has become a daily life (Briandana, Doktoralina, et al., 2020; Kaplan \& Haenlein, 2012).

In the current use of social media, it is more on promoting or publishing the activities of an agency or company as carried out by the Secretary General of the DPR-RI on the work activities of the leadership and members of the DPR-RI. In managing content, the DPR-RI social media team is required to have a strategy in mastering the issues to be used as content to be published on Instagram. In the author's findings, the DPR-RI social media team has carried out this, namely conducting observations and analysis of issues that are public discussion before the content is published. The observation steps carried out by the DPR-RI social media team were more on the Government's Instagram accounts to equalize the issues that were being discussed publicly. Fulfilling the public's wishes through content published by the DPR-RI's Instagram social media is a must, as is the purpose of using social media. Currently, the public who follows the DPR-RI's Instagram social media is solely to find out the performance of the members they have elected, and to wait what decisions DPR-RI members in responding to current problems make.
Based on the findings, several issues that are of public need are accommodated by the DPRRI social media team to be answered, such as the case of increasing BPJS (Health Social Security Administering Bodies) contributions, hajj funds and plastic waste. The social media team made these issues into content apart from the strategy and creativity in fulfilling the public's desire to see the performance of the leadership and members of the DPR-RI.

In the management of public information carried out by the DPR-RI social media aimed at realizing good governance, DPR-RI social media also take strategic actions from the long-term goals of the organization, namely by implementing the Public Information Openness Law No.14 of 2008. Initiated by the DPR-RI to achieve good governance, the DPR RI has a specific strategy that is committed to becoming a Modern Parliament. In realizing that, the DPR RI has a content strategy planning, namely towards a Modern Parliament, where one of the components of the modern parliament is transparency. Apart from that, in realizing good governance through public information, the DPR's social media conducts participatory activities with DPR Members in dealing with, anticipating, and managing organizational issues. Social media creates forums that facilitate the Leadership and Members of the DPR to be able to convey their work programs to the public, namely through social media, where the public can actively and interactively convey aspirations to DPR Members with the aim of managing organizational issues, perceptions and public opinion. The goal is content can encourage the audience to do what the content owner wants effectively (Panjaitan et al., 2019). Whereas accessibility is content everyone can access that equally, meaning that there are no restrictions on who can access the content, including audiences with disabilities (Jameel et al., 2019; Maria, 2020; Mehboob \& Othman, 2020). This means that managers must provide content in various formats so that messages can be consumed visually, textually interactively. 
The role of DPR-RI social media in smoothing the flow of public information is currently facing its own challenges in the midst of this situation (Boström et al., 2015). In the end, the DPR RI will find it difficult to manage public information and implement the concept of transparency to create a Modern Parliament in the context of achieving good governance. Herein lies the importance of coordination for the Social Media of the DPR RI to intervene by presenting alternative information that is comprehensive, intact and maintained. That way the public has alternatives in obtaining credible information from the DPR RI social media.

The steps to use Instagram by the DPR-RI social media team are inseparable from the advantages of features in Instagram, such as photos, videos, infographics, stories and live broadcasts which are very helpful in publishing the performance of DPR-RI leaders and members to achieve good government. In using Instagram as a place of promotion, it is required to have its own strategy and creativity in conveying messages through published content (Zappavigna, 2016). That is, the content to be published, including photos, videos, infographics and live broadcasts, must be strengthened by the editor in the posting description so that the message to be conveyed through videos, photos, infographics and live broadcasts is understood by the public (Jamil et al., 2019).

This study shows a number of issues that the community needs are accommodated by the DPR-RI social media team to be answered, such as the case for an increase in BPJS fees, and the management of hajj funds. This transparency of the information is as same as the implementation of The Law on Public Information Disclosure (Undang-Undang Keterbukaan Informasi Publik No. 14 Tahun 2008) initiated by DPR-RI to realize good governance.

Selection of Instagram as a communication channel because it has features such as photos, videos, infographics, stories and live broadcasts (Briandana \& Mukti, 2019). This content is strengthened by the editor in the posting information so that the message delivered contains clear information and understood by the public (Dwityas, Mulyana, et al., 2020). This study shows model Robert E. Simmons' of system communication campaigns that all elements of content planning are part of an integrated process that supports the goals to be achieved. Stages of the message strategy are a systematic arrangement that is connected to one another and carried out in a coordinated way (Labolo et al., 2020).

\section{CONCLUSION}

The conclusion of this research is that the communication strategy carried out by the DPR-RI provides good governance education, where the implementation of the strategy is to provide information transparency to the public. The information presented is what the community in accordance with the vision and mission of the DPR-RI needs. Through many Instagram features that people can choose the features, they would like to comment on. This communication channel becomes a suggestion for the leaders and members of the DPR in building their work program as the people's representatives. The DPR-RI's efforts to build a transparent political institution will be an indicator in forming a modern parliament, in accordance with the mandate of the Law on Public Information Disclosure through the management of public information that contains the use of information technology to open access of information to the public. This research can be a reference regarding good government education and communication strategies for other researchers, considering that good government can be implemented in all countries, especially regarding information disclosure.

\section{References}

[1] Anderson, M., \& Jiang, J. (2018). Teens, social media \& technology 2018. Pew Research Center, 31.

[2] Ahmad I, Ahmad S. Multiple Skills and Medium Enterprises' Performance in 
Punjab Pakistan: A Pilot Study. Journal of Social Sciences Research. 2018; Special, (4):44-9.

[3] Ahmad I, Ahmad S. The Mediation Effect Of Strategic Planning On The Relationship Between Business Skills And Firm's Performance: Evidence From Medium Enterprises in Punjab, Pakistan. Opcion. 2019;35(24):746-78.

[4] Ahmad, I., Sahar. Waste Management Analysis From Economic Environment Sustainability Perspective. International Journal Of Scientific \& Technology Research. 2019; 8(12), 1540-1543.

[5] Barker, M., \& Mathijs, E. (2012). Researching world audiences: The experience of a complex methodology. Participations, 9(2), 664-689.

[6] Beeri, I., Uster, A., \& Vigoda-Gadot, E. (2019). Does performance management relate to good governance? A study of its relationship with citizens' satisfaction with and trust in Israeli local government. Public Performance \& Management Review, 42(2), 241-279.

[7] Boström, M., Jönsson, A. M., Lockie, S., Mol, A. P. J., \& Oosterveer, P. (2015). Sustainable and responsible supply chain governance: challenges and opportunities. Journal of Cleaner Production, 107, 1-7.

[8] Briandana, R., \& Mukti, D. A. (2019). Understanding Photography Representation: Humanism and Social Criticism in Social Media. International Conference on Psychology and Communication 2018 (ICPC 2018).

[9] Briandana, R., Doktoralina, C. M., Hassan, S. A., \& Wan Hasan, W. N. (2020). Da'wah Communication and Social Media: The Interpretation of Millennials in Southeast Asia. International Journal of Economics and Business Administration, VIII(Special Issue 1), 216-226. https://doi.org/10.35808/ijeba/543
[10] Briandana, R., Pribadi, E., \& Balaya, S. (2020). MAPPING THE CONVERGENCE TRENDS OF TELEVISION BROADCASTING MEDIA IN INDONESIA. Bricolage: Jurnal Magister Ilmu Komunikasi, 6(2), 147-158. https://doi.org/DOI: 10.18502/kss.v2i4.871

[11] Datig, I. (2018). Revitalizing library websites and social media with content strategy: Tools and recommendations. Journal of Electronic Resources Librarianship, 30(2), 63-69.

[12] Dwityas, N. A., \& Briandana, R. (2017). Social media in travel decision making process. International Journal of Humanities and Social Sciences, 7(7), 291-292.

[13] Dwityas, N. A., Briandana, R., \& Aulia, P. (2020). Consumer journey of culinary products through social media in Indonesia. Humanities and Social Science Review, 8(1), 306-314. https://doi.org/https://doi.org/10.18510/hss r.2020.8141

[14] Dwityas, N. A., Mulyana, A., Hesti, S., Briandana, R., \& Putrianti, M. K. (2020). Digital Marketing Communication Strategies: The Case of Indonesian News ${ }^{6}$ Portals. International Journal of Economics and Business Administration, VIII(Issue 30), 307-316. https://doi.org/10.35808/ijeba/517

[15] Gane, N., \& Beer, D. (2008). New Media The Key Concept. Berg.

[16] Gerlich, R. N., Browning, L., \& Westermann, L. (2010). The social media affinity scale: Implications for education. Contemporary Issues in Education Research, 3(11), 35-42.

[17] Haftor, Darek, Mirijamdotter, \& Anita. (2010). Information and Communication Technologies, Society and Human Beings: Theory and Framework. Information Science Reference. 
[18] Hertati, L., Zarkasyih, W., Suharman, H., \& Umar, H. (2019). The effect of human resource ethics on financial reporting implications for good government governance (survey of related sub-units in state-owned enterprises in sumsel). International Journal of Economics and Financial Issues, 9(4), 267.

[19] Jameel, A., Asif, M., \& Hussain, A. (2019). Good Governance and Public Trust: Assessing the Mediating Effect of E-Government in Pakistan. Lex Localis, 17(2), 299-320.

[20] Jamil, A., Rekarti, E., Briandana, R., \& Audinna, S. (2019). The Role of Social Media Hashtags in Political Promotions: Mediating Role of Supply Chain Communication. International Journal of Supply Chain Management, 8(6), 181188.

https://doi.org/https://doi.org/10.4324/978 13157750

[21] Kaplan, A. M., \& Haenlein, M. (2012). Social media: back to the roots and back to the future. Journal of Systems and Information Technology, 14(2), 101-104.

[22] Labolo, M., Rohmansyah, H., \& Rumbekwan, M. (2020). Political Reforms and the Role of Parliament in Promoting Good Governance through the Integration of Religious Views in National Politics. Talent Development \& Excellence, 12(1), 3324-3330.

[23] Maria, A. (2020). Construction of an Industry Cycle Indicator for Profitability Prediction Analysis of Aggregate Firms in Bangladesh. International Journal of Social Sciences and Economic Review, 2(4), 918. doi:doi.org/10.36923/ijsser.v2i4.76

[24] Mehboob, F., \& Othman, N. (2020). Examining the Links Leading to Behavioral Support for Change: An Expectancy Theory Perspective. International Journal of Social Sciences and Economic Review, 2(4), 1-8. doi:10.36923/ijsser.v2i4.78

[25] Muda, I., Maulana, W., Sakti Siregar, H., \& Indra, N. (2018). The Analysis of Effects of Good Corporate Governance on Earnings Management in Indonesia with Panel Data Approach. Iranian Economic Review, 22(2), 599-625.

[26] Mulyana, A., Briandana, R., \& Ningrum, D. A. P. (2019). Social Construction Fandom as Cultural Industry Marketing of JKT 48 Fan Group. 12(3), 257-266. https://doi.org/https://doi.org/10.21632/irjb s.12.3.257-266

[27] Mulyana, A., Briandana, R., \& Rekarti, E. (2020). ICT and Social Media as a Marketing Communication Platform in Facilitating Social Engagement in the Digital Era. International Journal of Innovation, Creativity and Change, 13(5), $1-16$.

https://doi.org/https://doi.org/10.5267/j.usc m.2014.5.002

[28] Nadeem, M. A., Qamar, M. A. J., Nazir, M. S., Ahmad, I., Timoshin, A., \& Shehzad, K. (2020). How Investors Attitudes Shape Stock Market Participation in the Presence of Financial Self-Efficacy. Frontiers in Psychology, 11(2286), $1-10$. doi:10.3389/fpsyg.2020.553351

[29] Nasution, A. (2017). The government decentralization program in Indonesia. In Central and Local Government Relations in Asia. Edward Elgar Publishing.

[30] Obicci, S. P. A. (2019). Physical Asset Management Practices And Quality Service Delivery In Local Governments In Mid North Sub-Region Of Uganda. International Journal of Social Sciences and Economic Review, 1(2), 73-79. https://doi.org/10.36923/ijsser.v1i3.39

[31] Panjaitan, R. B., Sumartono, S., Sarwono, S., \& Saleh, C. (2019). The role of central government and local government and the 
moderating effect of good governance on forest fire policy in Indonesia. Benchmarking: An International Journal.

[32] Prihatini, E. S. (2019). Women's views and experiences of accessing National Parliament: Evidence from Indonesia. Women's Studies International Forum, 74, 84-90.

[33] Rauniar, R., Rawski, G., Yang, J., \& Johnson, B. (2014). Technology acceptance model (TAM) and social media usage: an empirical study on Facebook. Journal of Enterprise Information Management, 27(1), 6-30.

[34] Razzaq, S., Maqbool, N., \& Hameed, W. U. (2019). Factors Effecting The Elasticity Of Micro Credit Demand In Southern Punjab, Pakistan. International Journal of Social Sciences and Economic Review, $1(2)$, 46-53. https://doi.org/10.36923/ijsser.v1i2.34

[35] Rex, O. C. (2019). Poverty Elevation Amidst Poverty Alleviation Programmes In Nigeria. International Journal of Social Sciences and Economic Review, 1(2), 5460. https://doi.org/10.36923/ijsser.v1i2.38

[36] Safko, L., \& Brake, D. K. (2009). The social media bible: Tactics, tools, and strategies for business success. Wiley John $\&$ Sons.

[37] Sugiyono, M. (2012). Metode Penelitian Kuantitatif, Kualitatif, dan Kombinasi. In Alfabeta. Alfabeta.

[38] Sutono, A., Briandana, R., Doktoralina, C. M., Rekarti, E., \& Dwityas, N. A. (2018). Exploration of Marine Tourism in North Sumatra: An Analysis of Promoting Tourism. Journal of Social Studies Education Research, 9(4), 185-197.

[39] Yin, R. K. (2006). Case study methods. In Handbook of complementary methods in education research (Vol. 3). Routledge.

[40] Yin, R. K. (2013). Applications of case study research. In Applied Social Research Methods Series (Third). Sage Publications.
https://doi.org/10.1097/FCH.0b013e31822 dda9e

[41] Zappavigna, M. (2016). Social media photography: construing subjectivity in Instagram images. Visual Communication, 15(3), 271-292. 